\title{
UMIAR WE WSPÓKCZESNEJ ARCHITEKTURZE A POTENCJAK BUDOWNICTWA NATURALNEGO W OBLICZU KRYZYSU KLIMATYCZNEGO
}

DOI: 10.37660/integr.2020.6.2.1

\section{WSTĘP}

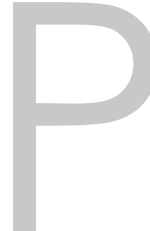

ostępujące zmiany klimatu i globalna degradacja środowiska spowodowana działaniem współczesnego człowieka oraz ich następstwa, takie jak kataklizmy naturalne czy niestabilne zjawiska pogodowe, wpływaja także na formę i funkcję dzisiejszej architektury. Ekologiczna odpowiedzialność architektów w kontekście postępujących zmian klimatycznych to temat badań, kłóry należy zgłębić. W pracy poddano analizie dział budownictwa bazujący na naturalnych materiałach. Architektura naturalna bowiem, połaczona z zachowaniem umiaru we współczesnej praktyce architektonicznej, może być potencjałem dla sektora budowlanego w obliczu wspomnianego kryzysu klimatycznego.

Antropogeniczność zmiany klimatu jest faktem. Najnowszy klimatyczny raport specjalny Międzyrzadowego Zespołu ds. Zmian Klimału’ z sierpnia 2019 roku, skupiający się m.in. na zrównoważonym zarządzaniu gruntami, podkreśla konieczność redukcji emisji CO2 przez wszystkie sektory gospodarki [4]. Zgodnie z raportem bardziej zrównoważone zarządzanie gruntami może przyczynić się do przeciwdziałania zmianom klimatu. Nie jest to jednak wystarczającym rozwiąaniem. Zmniejszenie emisji gazów cieplarnianych we wszystkich sektorach gospodarki jest niezbędne, by utrzymać globalne ocieplenie na poziomie znacznie poniżej $2^{\circ} \mathrm{C}$. Istotne jest więc skoncentrowanie wszelkich działań na zrównoważonym rozwoju także w sektorze budowlanym oraz architekturze. Konieczne sq zasadnicze zmiany w sposobie eksploatacji ziemskich zasobów, gdyż tempo zmian klimatycznych postępuje najszybciej w historii. Obecnie możemy mówić o najwyższych stężeniach CO2 na Ziemi od kilkunastu milionów lat [6, s. 36].

Sektor budowlany ponosi bowiem odpowiedzialność za 36\% końcowego zUżycia energii. Dodatkowo jego aktywność stanowi przyczynę 39\% emisji dwutlenku węgla do atmosfery, będącej konsekwencja procesów energetycznych i technologicznych (w roku 2018), z czego aż $11 \%$ było wynikiem produkcji materiałów budowlanych, takich jak stal, cement i szkło $[8$, s. 9,12). Co więcej, sektor budowlany w Unii Europejskiej jest odpowiedzialny za produkcję $36 \%$ całkowitej ilości odpadów [9]. Przyczyna jest podejście liniowe sektora do gospodarki, opierające się na ciagłym wzroście i nieustannej produkcji, przy jednoczesnym stałym generowaniu

mgr inż. arch. Matylda Gacek, https://orcid.org/0000-0003-4317-6033, Szkoła Doktorska Politechniki Wrocławskiej, dyscyplina: architektura i urbanistyka

Międzyrzadowy Zespół ds. Zmian Klimatu, z ang. Intergovernmental Panel on Climate Change (IPCC), bada globalne zmiany klimatyczne i wpływ działalności ludzkiej na klimat. 
kolejnych odpadów. Dodatkowo szacuje się, iż ilość produkowanej energii, kłóra konsumowana jest w budynkach, to blisko $50 \%$.

Powyższe liczby uświadamiaja konieczność przekształcenia dotychczasowego modelu sektora budowlanego z liniowego na cyrkularny, w którym raz użyte materiały przetworzone będa ponownie, a ilość odpadów zostanie zredukowana do minimum. Obecnie na architektach spoczywa ogromna odpowiedzialność zminimalizowania negatywnego wpływu sektora budowlanego na środowisko. Perspektywa dla tych działań może stać się bardziej powszechna praktyka architektury naturalnej, która w swojej istocie maksymalnie ogranicza wpływ na środowisko i bazuje na koncepcji gospodarki cyrkularnej.

\section{ANALIZA ARCHITEKTURY NATURALNEJ W KONTEKŚCIE ARCHITEKTURY BIOKLIMATYCZNEJ}

Współczesna architektura naturalna definiowana jest przez autorkę jako jeden z działów budownictwa zrównoważonego, opartego na zastosowaniu niskoprzetworzonych, naturalnych materiałów. Materiały te, w połaczeniu z odpowiednimi, bieżącymi technologiami budowy, sa niskoemisyjne i oddziałuja w zminimalizowany sposób na środowisko. Projekty architektoniczne, bazujące na naturalnych technologiach i uwzględniające wykorzystanie lokalnych właściwości klimatycznych danego obszaru, reprezentuja cechy architektury bioklimatycznej. Aktualnie istotne jest zbadanie możliwości projektowania architektury przystosowanej do coraz wyraźniej zmieniających się warunków klimatycznych. Przekształcenia klimatu są bowiem nieuniknione. Objawiaja się przede wszystkim gwałtownymi zmianami temperatur oraz drastycznymi zjawiskami pogodowymi, jak gwałtowne ulewy czy utrzymujące się susze. Co więcej, występowanie ekstremalnych zjawisk pogodowych prognozowane jest jako coraz częstsze [6, s. 79]. Zdaniem autorki należy zauważyć, iż w obecnym kontekście projektowym, w przypadku architektury bioklimałycznej, będącej wyrazem współdziałania architektury z klimatem, istołne sa dwa aspekty. Po pierwsze, stosowanie pasywnych rozwiqzań projektowych w celu zapewnienia odpowiedniego funkcjonowania budynku pod względem termicznym w danych warunkach klimatycznych. Po drugie, współcześnie pod uwagę należy brać także same materiały i technologie budowy wraz z szacunkowymi wartościami dwutlenku węgla, które generuja, tak by minimalizować negatywny wpływ praktyk architektonicznych na klimat. Realizując proces projektowy i budowalny zgodnie z przedstawionymi aspektami całościowego podejścia, można dostrzec wyraźny potencjał architektury naturalnej w kontekście architektury bioklimatycznej. Powszechnie praktykowana może stać się bardzo istotnym dla sektora budowlanego działem zmniejszającym jego negatywny wpływ na klimat i środowisko. Priorytetowy bowiem w przypadku architektury naturalnej jest jej wpływ na środowisko. We wzorcowym ujęciu człowiek i jego habitat traktowane sa jako jeden z wielu elementów całego ekosystemu, nie zaś człon dominujący, a wraz ze środowiskiem naturalnym pozostają w stanie równowagi.

Naturalne materiały budowlane, poza pochodzeniem oraz bardzo niskim stopniem przetworzenia, charakteryzuja się szeregiem korzystnych właściwości. Możliwych do wyboru jest wiele technologii. W powszechnym użyciu sq technologie wykorzystujace: drewno (Używane gównie do tworzenia szkieletowych konstrukcji nośnych); glinę (często funkcjonuje jako substancja wypełniająca 
oraz izolator); a także ubijana ziemia (z ang. rammed earth), która przy odpowiednim składzie może pełnić funkcje nośne (rys. 1). Do najbardziej popularnych w Polsce można zaliczyć dwie kolejne technologie. Pierwsza z nich to tzw. hempcrete, coraz szerzej stosowana technologia bazujaca na zastosowaniu betonu konopnego. Druga to tzw. strawbale, czyli budowa z wykorzystaniem słomy

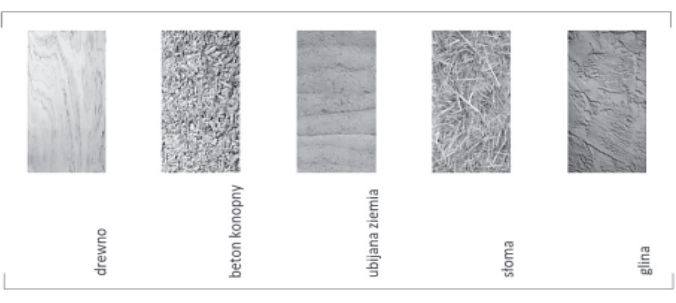

Rys. 1. Zestawienie naturalnych materiałów budowlanych będacych w obecnym powszechnym użyciu (opracowanie własne)

Fig. 1. The profile of natural building materials being in current common use (own study) wypełniajacej drewniany stelaż. Istotne sq łakże powierzchnie wykończeniowe stosowane równolegle z powyższymi materiałami. Sa to m.in.: tynki wapienne, wapienno-konopne czy gliniane. Sa one naturalnym uzupełnieniem przedstawionych technologii, podtrzymujacym paroprzepuszczalne właściwości samych materiałów budowlanych. Jest to zasadnicze, jeśli chodzi o jakość i cyrkulację powietrza we wnętrzach oraz ochronę samych przegród przed zawilgoceniem, a łym samym utrata właściwości izolacyjnych. Przegrody poziome zaś coraz częściej tworza posadzki gliniane realizowane zgodnie ze współczesnymi standardami.

Hempcrete ${ }^{2}$ określany jest jako współczesny wariant tradycyjnych materiałów budowlanych znanych ludzkości od wieków, jak szachulec czy standardowe połączenie gliny i słomy. To kompozył wapienno-konopny, kłóry powstaje poprzez zmieszanie paździerzy konopnych ${ }^{3}$ z wapiennym spoiwem oraz woda. Materiał ten może być przygotowywany bezpośrednio na miejscu budowy. Występuje wówczas w charakterze mieszanki rozprowadzanej wokół konstrukcji nośnej, tworząc monolityczna, szczelna strukturę budynku o zminimalizowanych mostkach termicznych. Warto podkreślić, iż beton konopny w postaci przygotowywanej bezpośrednio na miejscu budowy cechuje się najniższym śladem węglowym. Nie występuja dodatkowe zewnętrzne, energochłonne procesy produkcyjne, magazynowe oraz transportowe. Beton konopny występuje także w formie gotowych prefabrykatów - bloczków lub całych paneli. Dodatkowo hempcretem w formie monolitycznej czy zastosowanym jako prefabrykat można izolować istniejace już budynki ${ }^{4}$. Istotne dla budownictwa naturalnego sa próby opracowania nowych materiałów pochodzenia naturalnego, które spełniałyby także funkcję nośnq w budynku. Takim przykładem moga być cegły konopne, np. Cannabric, które daja możliwość zastosowania ich jako struktury zarówno nośnej, jak i wypełniającej. Jest to możliwe także w budynkach wielopiętrowych [1].

W Polsce najbardziej popularna naturalna technologia wznoszenia budynków jest tzw. strawbale. Polega na zastosowaniu kostek słomianych, kłóre wypełniaja

2 Z j. ang. hempcrete - beton konopny. W pracy oba terminy używane sa przez autorkę wymiennie z uwagi na powszechne użycie w języku polskim angielskojęzycznej nazwy.

3 Paździerze konopne - pocięte, zdrewniałe rdzenie łodyg konopi przemysłowych o dł. ok. $10-25 \mathrm{~mm}$.

4 Hempcrete jest materiałem korzystnym szczególnie do izolacji istniejacych już budynków, w tym historycznych - w takich obiektach niezwykle istotna jest paroprzepuszczalność, która zapewnia beton konopny. 
drewniana konstrukcję nośnq. Odpowiedniej jakości słoma zostaje uformowana w prostopadłościan (o wymiarach najczęściej ok: $35 \times 50 \times 60-75 \mathrm{~cm}$ ). Powinien być on dopasowany swoimi wymiarami do konstrukcji nośnej, a także dobrze ukształtowany (zbity i jednorodny). Dzięki temu powstała ściana będzie jednolita i solidna. Słoma wypełniająca ściany pełni rolę izolacji termicznej i akustycznej. Tak ocieplony budynek może być nawet pasywny [5, s. 10]. Co ważne, zapewnia także paroprzepuszczalność, którq wykluczaja komercyjnie stosowane materiały izolacyjne, np. styropian. Odmiana technologii strawbale jest konstrukcja samonośna ze słomy 5 , kłórej ściany wykonane sa wyłącznie z kostek słomy pełniacych funkcję nośna dla dachu (z niewielkimi usztywnieniami drewnianymi). Podobnie jak beton konopny konstrukcje z użyciem słomy sa realizowane bezpośrednio na placu budowy lub bazuja na gotowych prefabrykatach słomiano-drewnianych. Moga być to zarówno stosunkowo duże, pojedyncze, słomiane kostki, jak i całe gotowe ściany. Wpływa to w sposób znaczacy na tempo prac na placu budowy.

Architektura bioklimatyczna jest rozumiana jako wykorzystywanie lokalnych cech klimatycznych danego obszaru dla zapewnienia odpowiednich warunków środowiska wewnętrznego budynku, a tym samym zdrowia i komfortu użytkownika. Głównymi narzędziami używanymi dla tych celów sq rozwiq̨zania pasywne, których zastosowanie wpływa korzystnie na wydajność energetyczna budynków [2]. Te korzystne, pasywne cechy reprezentuje świadomie stosowana architektura naturalna. W przypadku technologii naturalnych możliwe do uzyskania w sposób pasywny sq odpowiednie pojemności cieplne przegród, przy jednoczesnym zapewnieniu stabilnego mikroklimatu wnętrz. Przykładowo, ściana wykonana z użyciem betonu konopnego reprezentuje pożądane połączenie: właściwości termoizolacyjnych ze znaczna masa termiczna. Ostatecznie tak wykonana przegroda w sposób pasywny zapobiega zarówno szybkiemu nagrzewaniu się, jak i wychładzaniu budynku, będąc jednocześnie odporna na takie skutki zmian klimałycznych, jak fale upałów i gwałtowne wahania temperatur.

Dodatkowo, naturalne materiały budowlane umożliwiaja swobodny przepływ wilgoci, są higroskopijne i paroprzepuszczalne. Ewentualna wilgoć, która dostanie się do przegrody, nie zostaje w niej zatrzymana. Dzięki temu zapewniony jest właściwy dla zdrowia stopień wilgotności powietrza we wnętrzach obiektów. W kontekście projekłowania zdrowych dla człowieka przestrzeni życiowych warto podkreślić, iż powszechnie używane syntetyczne materiały, m.in. izolacje termiczne, uwalniaja według wszelkiego prawdopodobieństwa substancje toksyczne i niebezpieczne dla zdrowia ludzkiego'. Co więcej, wraz ze wzrostem temperatury otoczenia (a tym samym temperatury pokojowej), a także wraz z podnoszeniem się ciśnienia atmosferycznego wzrasta emisja substancji toksycznych zawartych w materiałach budowlanych [7, s. 351]. Należy podkreślić, iż materiały pochodze8 nia naturalnego nie stwarzaja zagrożenia w przedstawionym kontekście, gdyż nie zawieraja żadnych substancji sztucznych i szkodliwych.

Reasumując, odpowiednio realizowana architektura naturalna może być zaklasyfikowana także jako architektura bioklimatyczna.

5 Tzw. strawbale loadbearing. Wykorzystanie tych konstrukcji znacznie oszczędza drewno, a drzewa rosna znacznie wolniej od słomy.

- Mowa o transpiracji chemikaliów, zwłaszcza łzw. LZO - lotnych związków organicznych, mogacych zanieczyszczać powietrze, a tym samym powodować szkody w zdrowiu użytkowników budynku [7]. 


\section{ŚLAD WĘGLOWY}

Powszechnym terminem określajacym stopień wpływu danego sektora gospodarki na kryzys klimatyczny jest ślad węglowy. Ślad węglowy to „Metoda mierzenia zarówno energii potrzebnej do wyprodukowania, jak i energii potrzebnej przy wykorzystywaniu, co pozwala na porównanie między różnymi metodologiami. Określanie śladu węglowego to działanie matematyczne wykorzystywane do obliczenia, ile $\mathrm{CO}_{2}$ rocznie dostaje się do atmosfery z $1 \mathrm{~m}^{2}$ budynku. Pozwala to na porównywanie danych dołyczacych wielu budynków wybudowanych przy użyciu różnych technologii" [7, s. 350].

Architektura naturalna bazuje na naturalnych, niskoprzetworzonych materiałach. Ich zasadnicza cecha, tak pożądaną w dobie postępujących zmian klimatycznych, jest niski, zerowy, a czasem nawet ujemny wskaźnik śladu węglowego. Wysoce istotne jest kompleksowe i priorytetowe podejście do aspektu śladu węglowego w architekturze. Do oceny wpływu budynków na środowisko służa konkretne narzędzia. Narzędzie, które szacuje wpływ budowli na środowisko, analizując przy tym wszystkie fazy życia budynku, to tzw. analiza cyklu życia budynku ${ }^{7}$. Analiza ta bazuje na podziale procesu da-

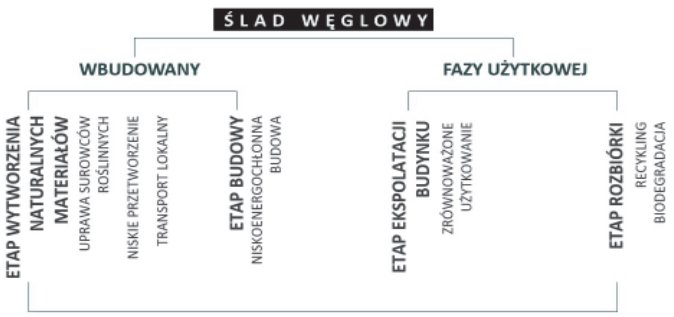

Rys. 2. Składowe analizy LCA cyklu życia budynku wykonanego w technologii naturalnej (opracowanie własne)

Fig. 2. Components of LCA analysis of the life cycle of the building made in natural technology (own study) nej inwestycji na jej poszczególne etapy (rys. 2). W ten sposób uwzględnia się cała energię wykorzystana w czasie istnienia danego budynku - poczawszy od jego powstania, poprzez użyłkowanie, aż po rozbiórkę.

Pierwsze stadium analizy obejmuje pomiar tzw. energii wbudowanej w dany materiał budowlany - to tzw. wbudowany ślad węglowy. Jest to równoznaczne z suma energii kolejnych etapów: energii potrzebnej do wyprodukowania danego materiału budowlanego, energii wykorzystanej do transportu materiału budowlanego na plac budowy oraz energii zużytej w procesie budowlanym.

Drugie stadium analizy poświęcone jest oszacowaniu tzw. śladu węglowego fazy użytkowej. Analiza ta rozpatruje okres tzw. całego życia budynku - poczawszy od momentu rozpoczęcia jego użytkowania, aż po etap łzw. końca życia obiektu - czyli rozbiórkę. Dokonuje się pomiaru sumy energii wykorzystanej podczas eksploatacji gotowego już budynku. Wynika ona bezpośrednio z przeznaczenia budynku, ze sposobu jego użyłkowania, a także jego energochłonności. Ostatecznie cały proces budowlany zostaje podzielony na poszczególne etapy, tak by zbadać dokładna i całościowa sumę emisji $\mathrm{CO}_{2}$ do atmosfery.

W opisanym powyżej kontekście technologie budowy bazujące na naturalnych materiałach prezentują się bardzo korzystnie - począwszy od pierwszego stadium analizy i etapu powstawania samych materiałów budowalnych. Rośliny

7 Tzw. z j. ang.: Lifecycle Analysis (LCA). 
stanowia podstawowy surowiec dla poddawanych analizie naturalnych materiałów budowlanych. Podczas wzrostu pobieraja dwutlenek węgla z atmosfery, tym samym magazynujac go w sobie. Stosowane surowce naturalne sa pozyskiwane wprost z upraw, nierzadko jako produkt uboczny hodowli roślin uprawnych na inne cele (np. słoma). Należy podkreślić, iż surowce te sq odnawialne. Sam proces przetworzenia surowców na materiały budowlane jest bardzo ograniczony i mało kosztowny energetycznie. Często etap produkcji finalnego materiału budowlanego odbywa się wprost na placu budowy (jak w przypadku mieszanki betonu konopnego w formie monolitycznej), ograniczając tym samym zewnętrzna fabrykację takiego materiału do zera. W tym przypadku zasadniczo obniżane sa emisje $\mathrm{CO}_{2}$ zwiq̨zane z produkcja materiałów budowlanych, które szacowane sa, zaraz po fazie użyłkowania budynku, jako etap najbardziej obciążający dla środowiska i pozostawiajacy największy ślad węglowy w atmosferze (rys. 2).

Co więcej, jako że analizowane materiały produkowane są najczęściej lokalnie, energia wykorzystana do ich transportu na plac budowy jest stosunkowo niewielka. Podczas etapu budowy obiektu w technologiach naturalnych ponownie oszczędzane są znaczne ilości energii w porównaniu z technologiami komercyjnymi. Ta faza bazuje zasadniczo na bezpośredniej pracy rą wykonawców, a obecność energochłonnych urządzeń mechanicznych jest mocno ograniczona. Jeśli zaś chodzi o drugie stadium analizy cyklu życia budynku - sumę energii wykorzystanej podczas jego eksploatacji - zależy ona w dużym stopniu od użytkownika i zastosowanych rozwiązań energetycznych. Przy tym już same naturalne materiały budowlane zapewniaja bardzo dobra izolację termiczną i pojemność cieplna, co wpływa niezwykle pozyływnie na gospodarkę energetyczna w budynku.

Wszystkie powyższe cechy wpływaja na to, iż materiały naturalne maja wyjątkowo niski ślad węglowy, a ich wpływ środowiskowy jest znikomy. Materiały te maja tzw. zdolność zamykania $\mathrm{CO}_{2}$ w strukturze budynku. Dzieje się tak z uwagi na fakt, iż surowcem naturalnych materiałów budowlanych sa rośliny. Oznacza to, iż podczas etapu uprawy i wzrastania rośliny absorbuje ona dwutlenek węgla z atmosfery. Po przetworzeniu roślinnych surowców na materiały budowlane to właśnie w strukturze budynku ostatecznie blokowany jest $\mathrm{CO}_{2}$, tak szkodliwy dla klimatu. Niepodważalna zaleta jest także możliwość magazynowania przez surowce roślinne takiej łącznej ilości $\mathrm{CO}_{2}$, która przewyższa sumę dwutlenku węgla wyłworzonego w fazie budowy obiektu ${ }^{8}$.

Podsumowując - energia niezbędna do wybudowania budynku w technologii naturalnej jest dużo niższa niż w przypadku technologii komercyjnych na każdym etapie życia budynku [7, s. 61].

\section{GOSPODARKA CYRKULARNA}

Obecny model gospodarki liniowej, oparty na ciagłym wzroście produkcji, powoduje zbył wydatne zużycie surowców naturalnych, a w konsekwencji - degradację całych regionów planety. Zmiana w tym zakresie jest konieczna. Świadomość dotycząca marnowania surowców naturalnych, szczególnie nieodnawialnych, musi być poszerzana. Zrównoważona i praktykowana świadomie architektura naturalna powinna działać w ramach modelu gospodarki cyrkularnej

8 Takie zjawisko definiuje termin tzw. ujemnego śladu węglowego. Warto podkreślić, iż jest to zjawisko cenne i pozytywne [7, s. 63]. 
(rys. 3). W takim przypadku odnawialne surowce roślinne staja się pierwszym ogniwem w całym cyklu obiegu materii (faza 1). W uważny, zaplanowany i odpowiedzialny sposób roślinna materia jest poddawana niskiemu przetworzeniu na materiały budowlane i transportowana lokalnie (faza 2). Następnie rozpoczyna się faza budowy obiektu w sposób maksymalnie niskoenergochłonny (faza 3). Po zakończonej budowie następuje faza najdłuższa - zrównoważonej eksploatacji budynku w sposób

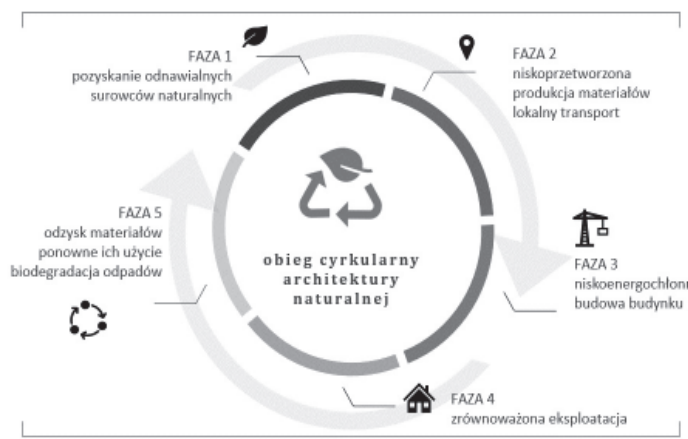

Rys. 3. Obieg materii w modelu cyrkularnym architektury naturalnej (opracowanie własne)

Fig. 3. Circulation of matter in the circular model of natural architecture (own study)

jak najmniej obciążajacy środowisko (faza 4). Końcem eksploatacji budynku jest moment jego rozbiórki, jednocześnie następuje maksymalny odzysk materiałów, a także możliwość ich ponownego użycia (faza 5). W przypadku technologii naturalnych w tej fazie zachodzi także biodegradacja niezdatnych do ponownego użycia naturalnych materiałów budowlanych z pierwotnego obiektu. W ten sposób następuje powrót surowców naturalnych do ekosystemu. Obieg materii zostaje zamknięty. Przy takim założeniu produkcja odpadów budowalnych sprowadzona jest do minimum, a elementy nadajace się do recyklingu są obligatoryjnie przetwarzane ponownie.

Z uwagi na powyższe architektura naturalna może być definiowana popularnym współcześnie terminem zero waste?, a więc modelem bezodpadowym. Warto podkreślić, iż zgodnie z szacunkami produkcja odpadów generowanych podczas budów przy użyciu technologii naturalnych jest zminimalizowana między 40 a aż $80 \%$ do analogicznych praktyk w standardowych komercyjnych technologiach [3]. Surowce naturalne to materiały odnawialne. Rośliny maja zdolność kolejnego wzrastania w relatywnie szybkim tempie. W ten sposób zasoby, które zużyto podczas wytwarzania naturalnych materiałów budowlanych, odnawiają się ponownie w krótkim czasie. Podczas obróbki tych materiałów sam proces przetwarzania jest dość prosty i pochłania stosunkowo niedużo energii oraz wody, a transport jest przeważnie lokalny. Wszystko to wpływa niezwykle pozytywnie na całościowy rozrachunek $\mathrm{CO}_{2}$ w przypadku budów przy zastosowaniu naturalnych materiałów budowlanych.

\section{PODSUMOWANIE}

W pracy połwierdzono użyteczność założeń architektury naturalnej dla współczesnego wymagajacego kontekstu projektowego. Podkreślono także zasadność świadomego praktykowania tych technologii zgodnie z idea gospodarki cyrkularnej. Przedstawiono uzasadnienie dla możliwości klasyfikacji odpowiednio praktykowanej architektury naturalnej jako architektury bioklimatycznej. Tym samym zaprezentowano potencjał technologii naturalnych $w$ tym kontek-

9 Z j. ang.: zero waste dosłownie ,zero odpadów”. To idea polegająca na zminimalizowanej lub zerowej produkcji odpadów, a także na niemarnowaniu już istniejących odpadów. 
ście jako stwarzających możliwość minimalizowania negaływnych skutków działalności sektora budowalnego. Materiały naturalne, jak hempcrete czy kostki słomy, to materiały o szczególnie niskim wpływie środowiskowym. Sa szansa na zminimalizowanie niezwykle negatywnego wpływu, jaki wywiera sektor architektury i budownictwa na środowisko, a więc na zmiany klimatyczne. Uzasadniono także, iż energia niezbędna do wybudowania budynku w technologii naturalnej jest dużo niższa niż w przypadku technologii komercyjnych. Co więcej potwierdzono, iż materiały naturalne maja wyjątkowo niski ślad węglowy. Omówione surowce reprezentuja także istotna i wyjątkowo korzystna współcześnie cechę tzw. zamykania $\mathrm{CO}_{2}$ w strukturze budynku. Dzisiejsza architektura naturalna nie jest jednoznaczna z rezygnacja z wypracowanej przez lata wiedzy z zakresu architektury i budownictwa. To świadome użycie prostych, naturalnych i dostępnych materiałów przy zastosowaniu współczesnych technologii. Nadrzędnym celem jest zminimalizowanie wpływu sektora budowlanego na pogłębianie kryzysu klimatycznego. Jako ludzkość jesteśmy w momencie, w którym sam kryzys nie może być dłużej poddawany w wątpliwość. Katastrofa klimatyczna jest niepodważalnym faktem, a wszelkie działania, we wszystkich sektorach, sq konieczne i musza być nagłe.

\section{LITERATURA}

[1] Cannabric, 2019. Cannabric - thermal, acoustic and bioclimatic control. http://www.cannabric.com/ (dostęp: 17.05.2019).

[2] Couvelas A., 2019. Bioclimatic building design theory and application. The lst International Conference on Optimization-Driven Architectural Design (OPTARCH 2019), https://www.sciencedirect.com/science/article/pii/ S2351978920308258 (dostęp: 09.05.2020).

[3] Ekodama Architektura, http://ekodama.pl/pl/technologie (dostęp: 18.04.2020).

[4] IPCC, 2019. Special report. Climate Change and Land. https://www.ipcc.ch/ srccl/ (dostęp: 28.04.2019).

[5] Minke G., Krick N., 2015. Podręcznik budowania z kostek słomy. Fundacja Cohabitat, Łódź.

[6] Popkiewicz M., Kardaś A., Malinowski Sz., 2019. Nauka o klimacie. Wydawnictwo Nieoczywiste, Warszawa.

[7] Stanwix W., Sparrow A., 2016. Podręcznik budowania z konopi. Fundacja Cohabitat, Łódź.

[8] UN Environment Programme, 2019. 2019 Global Status Report for Buildings and Construction. http://wedocs.unep.org/bitstream/handle/20.500.11822/ 30950/2019GSR.pdf? sequence=1 \&isAllowed=y (dostęp: 17.02.2019).

[9] Waste Statistics UE, 2019. https://ec.europa.eu/eurostat/statistics-explained/ pdfscache/14286.pdf (dostęp: 15.04.2019). 


\section{UMIAR WE WSPÓKCZESNEJ ARCHITEKTURZE A POTENCJAK BUDOWNICTWA NATURALNEGO W OBLICZU KRYZYSU KLIMATYCZNEGO}

STRESZCZENIE. Postępujace zmiany klimatu i globalna degradacja środowiska spowodowana działaniem współczesnego człowieka oraz ich następstwa, np. kałaklizmy naturalne czy niestabilne zjawiska pogodowe, wpływaja także na formę i funkcję dzisiejszej architektury. Ekologiczna odpowiedzialność architektów w kontekście postępujących zmian klimatycznych to temat badań, kłóry należy zgłębić. W pracy podjęto się analizy założeń wypracowanych w dziedzinie architektury naturalnej, istotnych dla współczesnych wyzwań projektowych ze względu na niski ślad węglowy i energetyczny. W publikacji przedstawiono nowoczesne naturalne budownictwo jako przestrzeń architektonicznego potencjału do walki z następstwami kryzysu klimatycznego i osiagnnięcia umiaru w eksploatacji zasobów naturalnych. Potwierdzono użyteczność założeń architektury naturalnej dla współczesnego wymagającego kontekstu projektowego i podkreślono zasadność świadomego praktykowania tych technologii w duchu gospodarki cyrkularnej.

Słowa kluczowe: architektura bioklimatyczna, zmiany klimatyczne, architektura naturalna, budownictwo naturalne

\section{MODERATION IN CONTEMPORARY ARCHITECTURE AND THE POTENTIAL OF NATURAL CONSTRUCTION IN THE FACE OF THE CLIMATE CRISIS}

SUMMARY. The progressive climate changes and global environmental degradation caused by the actions of modern man, and their consequences, such as natural disasters or unstable weather phenomena, also affect the form and function of today's architecture. The environmental responsibility of architects in the context of advancing climate change is a research topic that should be explored. The study undertakes to analyze the assumptions developed in the field of natural architecture, relevant to contemporary design challenges due to the low carbon and energy footprint. The aim of the article is to examine modern natural construction as a space for architectural potential to fight the consequences of the climate crisis and achieve moderation in the exploitation of natural resources. The work confirms the usefulness of natural architecture assumptions for the contemporary demanding design context and emphasizes the legitimacy of the conscious practice of these technologies in the spirit of circular economy.

Key words: bioclimatic architecture, climat changes, natural construction 